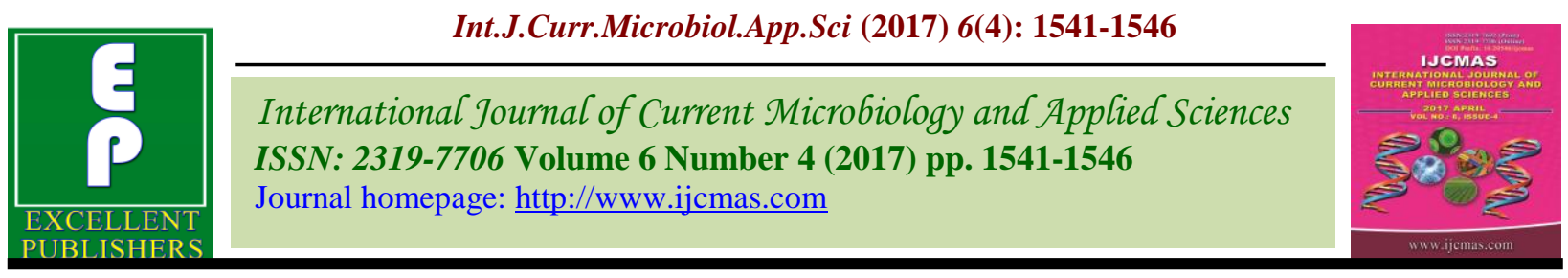

Original Research Article

https://doi.org/10.20546/ijcmas.2017.604.189

\title{
Management of Chilli (Capsicum annuum L.) Thrips and Mites Using Organics
}

\author{
M. Devi ${ }^{*}$, R.F. Niranjana ${ }^{2}$ and K. Indirakumar ${ }^{3}$ \\ ${ }^{1}$ Department of Agricultural Entomology, TNAU, Coimbatore, Tamil Nadu, India \\ ${ }^{2}$ Department of Agricultural Biology, Faculty of Agriculture, Eastern University Sri Lanka, \\ Chenkalady, SriLanka \\ Department of Agricultural Entomology, TNAU, Coimbatore, India \\ *Corresponding author
}

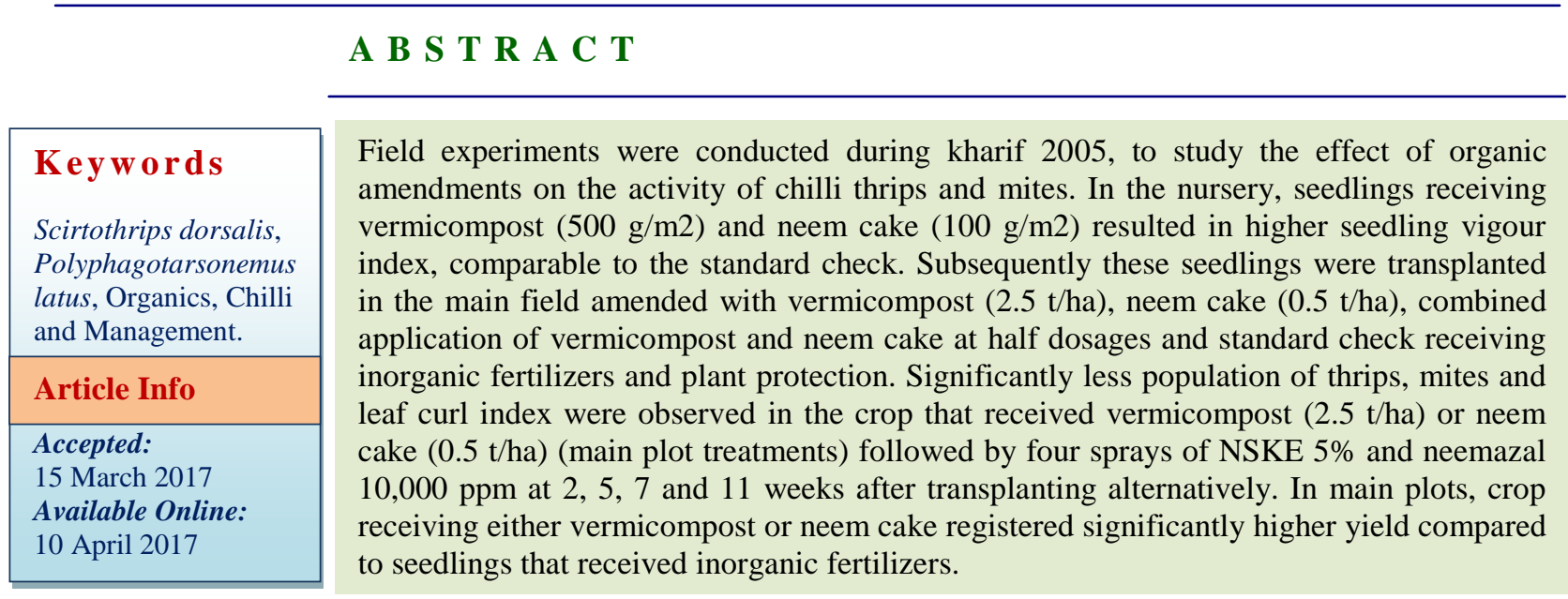

\section{Introduction}

Chilli (Capsicum annuum L.) is a tropical and subtropical crop grown all over India. Also known as 'red pepper', it is one of the most important commercial spice crops, earning valuable foreign exchange for the country. India produces about 10.70 lakh tonnes of chilli from an area of 9.08 lakh hectares. Of the total production, about $90-95$ per cent is consumed within the country and about 5-10 per cent is exported in the form of dry chilli, chilli powder and oleoresins (Singhal, 2003). Among the constraints in chilli cultivation, the attack of a multitude of insect pests and mite at different crop stages is of utmost concern.
Surveys conducted the major pests that attack chilli are aphids (Myzus persicae Sulzer, Aphis gossypi Glover), mite (Polyphagotarsonemus latus Banks) and thrips (Scirtothrips dorsalis Hood) (Berke and Sheih, 2000), which have been identified as main sucking pests of Byadagi chilli in Karnataka. Due to monoculture of chilli, nowa-days pest build up is so much that farmers have to resort to minimum of 5 to 6 chemical sprays. Numbers of sprays have increased over the years, but in vein and on the contrary, cost of cultivation has increased enormously making cultivation of chilli highly risky and non-profitable. In addition to 
this, these pesticidal sprays became a threat to chilli ecosystem causing resurgence of pests and menace to natural enemy fauna. Pesticide residues in chilli are also of great concern from the point of domestic consumption and exports as well. It is therefore imperative to resort to other non-chemical pest management strategies such as use of organic amendments, botanical pesticides and bioagents (key components of organic farming), which are eco-friendly and completely safe to the consumers.

\section{Materials and Methods}

Field investigations were carried out for the evaluation of organics in the management of thrips, Scirtothrips dorsalis and mite, Polyphagotarsonemus latus on chilli (cv. Byadagi) during the year 2012, at Pandit Jawaharlal Nehru College of Agriculture and Research Institute, Karaikal, under rainfed conditions. In the experiment on seedling vigour, Byadagi chilli seeds were sown during first fortnight of June in the nursery beds (0.6 $\mathrm{x} 0.9 \mathrm{~m}$ ) laid out in RBD. Vermicompost, neem cake and combined application of vermicompost and neem cake were evaluated $\mathrm{v} / \mathrm{s}$ the standard practice (check) for assessing the seedling vigour. Seedling vigour index (SVI) as suggested by Abdul Bavi and Anderson (1973) was calculated for 35 days old seedlings. Fifty such plants were selected from each replication and SVI was calculated by the formula: Seedling Vigour Index = Germination $(\%) \mathrm{x}$ seedling length $(\mathrm{cm})$ The best two organic treatments (receiving vermicompost and neem cake) in nursery were selected based on the Seedling Vigour Index and transplanted in the main field along with seedlings of standard check in split plot design. Main plot treatments included two organic amendments alone, a combination of organic amendments and 100\% RDF + FYM + RPP as standard check. The best two organically raised seedlings referred as above were the sub plots along with the standard check. The sprays were taken up at 2, 5, 7 and 11 weeks after transplanting from 45 DAT, using high volume knapsack sprayer. Observations were taken on the population of thrips and mites as per the destructive sampling and the experimental crop was scored for LCI in the scale 0-4 as described by Niles, 1980. Dry chilli yield observed for each plot was converted for hectare basis. The data presented in the table is the mean of all the observations.

\section{Results and Discussion}

The results of the experiment carried out to evaluate the effects of organics on seedling vigour in the nursery revealed that, vermicompost @ 500 g/m2 and neem cake @ $100 \mathrm{~g} / \mathrm{m} 2$ registering SVI of 941.19 and 927.10 , respectively were found superior to the rest of the treatments and were comparable to the standard check (964.7) which received FYM, NPK and plant protection. Lower dosages of vermicompost (T1), neem cake (T3) and combined applications of the two at half the rates (T5,T6, T7, T8) registered significantly lower SVI vis-à-vis sole applications at higher quantities (T2 and T4) (Table 1).

The ability of vermicompost to enhance the seedling vigour can be attributed to the fact that vermicompost contains both major and minor plant nutrients in available forms, besides enzymes, antibiotics, vitamins and plant growth hormones and have definite advantage over other organic manures (Meerabai and Asha, 2001). Neem cake contains good amount of organic nitrogen (2.0 to $2.5 \%$ ) and other nutrients besides various insect antifeedent constituents which might be the possible reason for good seedling vigour found in the experimentation. The present results could be compared with the only report in the form of preliminary findings of 
Giraddi and Tatagar (2004) who reported that seedlings raised with vermicompost application in the nursery were more vigourous by appearance and attracted less pests in the main field. The data on the population of thrips and mites as influenced by different soil amendments applied at planting and organically raised seedlings given in tables 2 and 3. Among the main plot treatments, sole application of vermicompost or neem cake followed by four sprays registered lower thrips (0.45 to $0.51 /$ leaf) and mite $(0.60$ and $0.64 /$ leaf $)$ numbers vis-àvis combined application (0.66 and 1.03 thrips and mites/leaf, respectively), but being at par with the check ( 0.34 and 0.33 thrips and mites/leaf, respectively). Although the check plots scored significantly lower LCI $(0.46)$ the crop that received vermicompost and four sprays registered at par LCI followed by neem cake and four sprays $(0.77$ and 0.87 , respectively).

Table.1 Germination per cent, seedling length and seedling vigour index of chilli in nursery as influenced by organics

\begin{tabular}{|c|c|c|c|c|}
\hline S. No & Treatments & $\underset{\%}{\text { Germination }}$ & $\begin{array}{l}\text { Seedling } \\
\text { length } \\
(\mathrm{cm})\end{array}$ & SVI \\
\hline 1. & Vermicompost@250 g/m2 & $75.30(62.45)$ & $9.85 b$ & $702.52 b$ \\
\hline 2 & Vermicompost @ 500 g/m2 & $78.83(64.69)$ & $12.46 \mathrm{a}$ & $941.19 \mathrm{a}$ \\
\hline 3 & Neem cake@ $50 \mathrm{~g} / \mathrm{m} 2$ & $75.30(62.56)$ & $9.73 b$ & $676.76 b$ \\
\hline 4 & Neem cake @ 100 g/m2 & $79.00(64.56)$ & $11.95 \mathrm{a}$ & $927.10 \mathrm{a}$ \\
\hline 5 & VC@ 250 g/m2 + NC @ 50 g/m2 & $76.00(63.59)$ & $8.55 b$ & $627.35 b$ \\
\hline 6 & VC@250 g/m2 + NC @100 g/m2 & $74.83(62.66)$ & $9.29 b$ & $650.94 b$ \\
\hline 7 & VC @ $500 \mathrm{~g} / \mathrm{m} 2+\mathrm{NC} @ 50 \mathrm{~g} / \mathrm{m} 2$ & $75.16(62.70)$ & $8.55 b$ & $643.56 b$ \\
\hline 8 & VC@ @ $500 \mathrm{~g} / \mathrm{m} 2+\mathrm{NC} @ 100 \mathrm{~g} / \mathrm{m} 2$ & $74.3(62.09)$ & $9.17 b$ & $658.91 b$ \\
\hline 9 & $\begin{array}{l}\text { FYM @ } 45 \mathrm{~g} / \mathrm{m} 2+\mathrm{C} . \text { fertilizer @ } 50 \\
\mathrm{~g} / \mathrm{m} 2\end{array}$ & $74.00(62.01)$ & $8.97 b$ & $618.09 b$ \\
\hline \multirow[t]{4}{*}{10} & T9 + RPP (Chemical interventions) & $80.30(66.12)$ & $12.18 \mathrm{a}$ & $964.77 \mathrm{a}$ \\
\hline & SEm+ & 1.44 & 0.0668 & 27.84 \\
\hline & $\mathrm{CD}$ & 0.195 & NS & 82.71 \\
\hline & $\mathrm{CV}$ & 3.93 & 3.57 & 6.51 \\
\hline
\end{tabular}

Figures in parenthesis are arc sin transformed values, Means in the rows and columns followed by the same alphabet do not differ significantly by DMRT $(\mathrm{P}=0.05)$ 
Table.2 Mean population of thrips influenced by organics in nursery and in the main field

\begin{tabular}{|c|c|c|c|c|c|}
\hline \multirow{3}{*}{$\begin{array}{l}\text { Main plot and } \\
\text { sub plot }\end{array}$} & \multicolumn{5}{|c|}{ Mean populations } \\
\hline & \multicolumn{5}{|c|}{ Thrips/leaf } \\
\hline & $\mathrm{VC} 2.5+\mathrm{NN}$ & $\mathrm{NC} 0.5+\mathrm{NN}$ & Vc1.25Nc 2.5 & RPP & Mean \\
\hline S1 & $0.41(0.954)$ & $0.47(0.985)$ & $0.52(1.010)$ & $0.33(0.911)$ & $0.43 b(0.964)$ \\
\hline $\mathrm{S} 2$ & $0.45(0.975)$ & $0.51(1.005)$ & $0.57(1.034)$ & $0.37(0.933)$ & $0.48 \mathrm{ab}(0.990)$ \\
\hline S3 & $0.49(0.995)$ & $0.55(1.025)$ & $0.90(1.183)$ & $0.33(0.911)$ & $0.57 \mathrm{a}(1.034)$ \\
\hline Mean & $0.45 \mathrm{ab}(0.975)$ & $0.51 \mathrm{ab}(1.005)$ & $0.66 \mathrm{a}(1.077)$ & $0.34 \mathrm{~b}(0.917)$ & $0.49(1.049)$ \\
\hline \multicolumn{2}{|c|}{ Comparison of mean } & SEm & CDat $5 \%$ & & \\
\hline Main (M) & & 0.042 & 0.138 & & \\
\hline Sub $(\mathrm{S})$ & & 0.018 & 0.055 & & \\
\hline InteractionMxS & & 0.183 & NS & & \\
\hline $\mathrm{CV}(\%)$ & & 9.75 & & & \\
\hline
\end{tabular}

VC - Vermicompost NC - Neem cake NN - Neem seed kernel extract and Neemazal sprays, RPP - Recommended package of practices DAT - Days after transplanting, S1 - Seedlings receiving vermicompost in nursery, NS Non-significant S2 - Seedlings receiving neem cake in nursery, S3 - Seedlings receiving RPP in nursery, Means in the rows and columns followed by the same alphabet do not differ significantly by DMRT $(\mathrm{P}=0.05)$, Figures in parenthesis are $\sqrt{ } \mathrm{x}+0.5$ transformed values

Table.3 Mean population of mites influenced by organics in nursery and in the main field

\begin{tabular}{|l|l|l|l|l|l|}
\hline \multicolumn{7}{|c|}{ Mean mite populations/leaf } \\
\hline S1 & VC 2.5 +NN & NC 0.5+NN & VC 1.25 Nc 2.5 & RPP & Mean \\
\hline S2 & $0.57(1.034)$ & $0.61(1.054)$ & $0.64(1.068)$ & $0.37(0.933)$ & $0.55 \mathrm{~b}(1.025)$ \\
\hline S3 & $0.60(1.049)$ & $0.64(1.068)$ & $0.69(1.091)$ & $0.34(0.917)$ & $0.57 \mathrm{ab}(1.034)$ \\
\hline Mean & $0.63(1.063)$ & $0.67(1.082)$ & $1.75(1.500)$ & $0.29(0.889)$ & $0.83 \mathrm{a}(1.153)$ \\
\hline Comparison of mean & $0.60 \mathrm{ab}(1.068)$ & $0.64 \mathrm{ab}(1.235)$ & $1.03 \mathrm{a}(0.911)$ & $0.33 \mathrm{~b}$ & 0.65 \\
\hline Main (M) & & SEm & CDat 5\% & & \\
\hline Sub (S) & & 0.106 & 0.320 & & \\
\hline InteractionMxS & & 0.452 & 0.123 & & \\
\hline CV (\%) & & 10.02 & $\mathrm{NS}$ & & \\
\hline
\end{tabular}

VC - VermicompostNC - Neem cake NN - Neem seed kernel extract and Neemazal sprays, RPP - Recommended package of practices DAT - Days after transplanting, S1 - Seedlings receiving vermicompost in nursery, NS - Nonsignificant S2 - Seedlings receiving neem cake in nursery, S3 - Seedlings receiving RPP in nursery, Means in the rows and columns followed by the same alphabet do not differ significantly by DMRT $(\mathrm{P}=0.05)$, Figures in parenthesis are $\sqrt{ } \mathrm{x}+0.5$ transformed values. 
Table.4 Dry chilli yield as influenced by organics applied in nursery and main field

\begin{tabular}{|c|c|c|c|c|c|c|}
\hline Sl. No. & Main /Sub & M1 & M2 & M3 & M4 & Mean \\
\hline 1 & S1 & 2.75 & 2.54 & 2.50 & 3.90 & $2.92 a$ \\
\hline 2 & S2 & 2.54 & 2.45 & 2.25 & 3.60 & $2.71 \mathrm{a}$ \\
\hline \multirow[t]{2}{*}{3} & S3 & 2.20 & 2.20 & 1.25 & 3.47 & $2.28 b$ \\
\hline & Mean & $2.49 b$ & $2.39 \mathrm{bc}$ & $2.00 \mathrm{c}$ & $3.65 \mathrm{a}$ & 2.63 \\
\hline Comparisonof Means & SE m+ & $\mathrm{CD}$ at $5 \%$ & & & & \\
\hline Main (M) & 0.154 & 0.457 & & & & \\
\hline Sub (S) & 0.085 & 0.251 & & & & \\
\hline \multirow{2}{*}{$\begin{array}{l}\text { Interaction (M x S) } \\
\mathrm{CV}(\%)\end{array}$} & 0.852 & NS & & & & \\
\hline & \multicolumn{6}{|l|}{18.84} \\
\hline
\end{tabular}

VC - Vermicompost NC - Neem cake NN - Neem seed kernel extract and Neemazal sprays, RPP - Recommended package of practices DAT - Days after transplanting S1 - Seedlings receiving vermicompost in nursery, NS - Nonsignificant S2 - Seedlings receiving neem cake in nursery S3 - Seedlings receiving RPP in nursery, Means in the rows and columns followed by the same alphabet do not differ significantly by DMRT $(\mathrm{P}=0.05)$

In the sub plots, seedlings raised with vermicompost in nursery and receiving organics and 4 sprays in main field supported lower thrips, mite density and LCI, being superior to the check (S3). This was followed by $\mathrm{S} 2$ being at par with the check (S3). Whereas Vermicompost@ 1.25 t/ha +Neem cake@0.25 t/ha + neem seed kernal extract and neemazal sprays was least effective with reference to leaf curl index (0.87). Varma and Supare (1997) and Varghese (2003) with low NPK observed significantly lower activity of thrips and mite in chilli amended with vermicompost and the present study is also in close agreement with these reports. The superior effect of neem cake in the present study is in line with the findings of Varghese and Giraddi (2005) who reported that neem cake@ $500 \mathrm{~kg} / \mathrm{ha}$ along with 50\% RDF (NPK) in combination with two and three sprays of RPP (dimethoate $30 \mathrm{EC} /$ dicofol 18.5 EC) was superior to RPP (100\% NPK and four chemical sprays) in having least population of thrips and mite which ultimately resulted in reduction in chemical interventions in crop ecosystem.

The pesticidal action of neem seed kernel extract (NSKE) which was superimposed in organically amended crop in the present study is in agreement with the findings of Varghese (2003) who observed that neem seed kernal extract and neem oil 5\% recorded lowest incidence of thrips and mites in chilli. Sashidhara (1999) reported that vermicompost along with $100 \%$ RDF recorded less leaf curl index compared to $100 \%$ RDF alone and results of the present experiment are in conformity with this. The property of neem cake in reducing the leaf 
curl was reported by Varghese and Giraddi (2005) who found that neem cake in combination with 50\% RDF and two and three sprays $\mathrm{v} / \mathrm{s}$ four sprays of chemicals recorded least leaf curl index. Among the organics tested, maximum dry chilli yield of 2.49 q/ha was obtained in Vermicompost @ $2.5 \mathrm{t} / \mathrm{ha}+$ neem seed kernal extract $(5 \%)$ and neemazal sprays followed by Neem cake @ $0.5 \mathrm{t} / \mathrm{ha}+$ neem seed kernal extract and neemazal sprays which recorded 2.39 q/ha, however maximum yield was registered in the standard check, i.e. $3.65 \mathrm{q} / \mathrm{ha}$. Among the organically raised seedlings evaluated, S1 receiving vermicompost out yielded the rest of the treatments by recording a yield of 2.92 q/ha (Table 4).

\section{References}

Abdul Bavi, Anderson, J.D. 1973. Vigour determination in soybean by multiple criteria. Crop Sci., 13: 630-633.

Anonymous. 2004. Improved cultivation practices for field crops, Final Technicla Report. University of Agricultural Sciences, Dharwad, pp: 227-234.

Berke, T. and Sheih, S.C. 2000. Chilli peppers in Asia. Capsicum and Egg Plant Newslett., 19: 38-41.

Giraddi, R.S. and Tatagar, M.H. 2004. Studies on seedling vigour enhancement through vermicompost in Byadagi chilli. Res. Highlights of Department of Entomol., University of Agricultural
Sciences, Dharwad, p. 15.

Meerabai, M. and Asha, K.R. 2001. Biofarming in Vegetables. Kisan World, 28: $15-16$.

Niles, G.A. 1980. Breeding cotton for resistance to insect pests. In Breeding Plant Resistance to Insects, Macwell. F.G and Jennings, (Eds) P.R John Wiley and Sons, New York, pp. 337-369.

Sashidhara, G.B. 1999. Integrated nutrient management for chilliin alfisols of northern transition zone of Karnataka. Ph.D. thesis, University of Agricultural Sciences, Dharwad, India.

Singhal, V. 2003. Chillies. In Indian Agriculture 2003, Indian Economic Data Research Centre, Mayapuri, New Delhi, pp. 565-570.

Varghese, T.S. and Giraddi, R.S. 2005. Integration of neem cake in the plant protection schedule for thrips and mite management in chilli (cv. Byadagi). Karnataka J. Agri. Sci., 18: 154-156.

Varghese, T.S. 2003. Management of thrips, Scirtothrips dorsalis Hood and mite, Polyphagotarsonemus latus (Banks) on Chilli using biorationals and imidacloprid. M.Sc (Agri) thesis, University of Agricultural Sciences, Dharwad, India.

Varma, N.R. and Supare, G. 1997. Effect of vermicompost in combination with FYM and chemical fertilizers against sucking pests of chilli. The Andhra Agri. J., 44: 186-187.

\section{How to cite this article:}

Devi, M., R.F. Niranjana and Indirakumar, K. 2017. Management of Chilli (Capsicum annuum L.) Thrips and Mites Using Organics. Int.J.Curr.Microbiol.App.Sci. 6(4): 1541-1546. doi: https://doi.org/10.20546/ijcmas.2017.604.189 